\title{
Ischemic stroke after pellet embolization
}

回

\section{Figure Imaging}
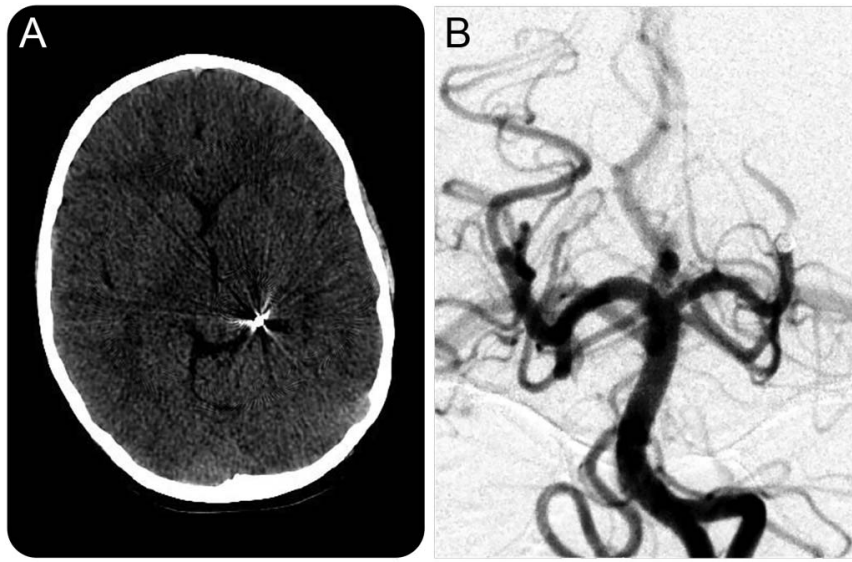

(A) Noncontrast head CT shows a pellet in the left ambient cistern. (B) Catheter-based angiogram shows the pellet in the left posterior cerebral artery with distal flow.

A 9-year-old boy was shot with a pellet shotgun and developed a visual field deficit. Head CT revealed a pellet in the left ambien cistern, in the left posterior cerebral artery on catheter angiography (figure). Chest fluoroscopy revealed multiple thoracic pellets, including a mobile cardiac pellet (video on the Neurology ${ }^{\circledR}$ Web site at Neurology.org). There was no clear cardiac injury, patent foramen ovale, or skull penetration. Arterial embolization of a pellet from the chest to the intracranial vasculature likely caused a stroke. ${ }^{1,2}$ We considered arteriotomy, endovascular retrieval, and medical therapy. The established infarct, clinical stability, and flow distal to the pellet argued for conservative treatment; the visual field deficit was unchanged at 1-month follow-up visit.

Amin Aghaebrahim, MD, Dan-Victor Giurgiutiu, MD, Brian T. Jankowitz, MD, Tudor Jovin, MD, Ashutosh P. Jadhav, MD, PhD

From the University of Pittsburgh Medical Center, University of Pittsburgh, PA.

Author contributions: Dr. Aghaebrahim: drafting/revising the manuscript, acquisition of data. Dr. Giurgiutiu: acquisition of data. Dr. Jankowitz: acquisition of data. Dr. Jovin: acquisition of data. Dr. Jadhav: drafting/revising the manuscript, acquisition of data. Study funding: No targeted funding reported.

Disclosure: The authors report no disclosures relevant to the manuscript. Go to Neurology.org for full disclosures.

Correspondence to Dr. Jadhav: jadhavap@upmc.edu

Supplemental data at Neurology.org
1. Stein M, Mirvis SE, Wiles CE. Delayed embolization of a shotgun pellet from the chest to the middle cerebral artery. J Trauma 1995;39:1006-1009.

2. da Costa LB, Wallace MC, Montanera W. Shotgun pellet embolization to the posterior cerebral circulation. AJNR Am J Neuroradiol 2006;27:261-263. 


\title{
Neurology
}

\author{
Ischemic stroke after pellet embolization \\ Amin Aghaebrahim, Dan-Victor Giurgiutiu, Brian T. Jankowitz, et al. \\ Neurology 2015;84;2383 \\ DOI 10.1212/WNL.0000000000001667
}

This information is current as of June 8, 2015

\begin{tabular}{|c|c|}
\hline $\begin{array}{l}\text { Updated Information \& } \\
\text { Services }\end{array}$ & $\begin{array}{l}\text { including high resolution figures, can be found at: } \\
\text { http://n.neurology.org/content/84/23/2383. full }\end{array}$ \\
\hline Supplementary Material & $\begin{array}{l}\text { Supplementary material can be found at: } \\
\text { http://n.neurology.org/content/supp1/2015/06/06/WNL.0000000000001 } \\
\text { 667.DC1 }\end{array}$ \\
\hline References & $\begin{array}{l}\text { This article cites } 2 \text { articles, } 0 \text { of which you can access for free at: } \\
\text { http://n.neurology.org/content/84/23/2383.full\#ref-list-1 }\end{array}$ \\
\hline Subspecialty Collections & $\begin{array}{l}\text { This article, along with others on similar topics, appears in the } \\
\text { following collection(s): } \\
\text { All Cerebrovascular disease/Stroke } \\
\text { http://n.neurology.org/cgi/collection/all_cerebrovascular_disease_strok } \\
\text { e Embolism } \\
\text { http://n.neurology.org/cgi/collection/embolism }\end{array}$ \\
\hline Permissions \& Licensing & $\begin{array}{l}\text { Information about reproducing this article in parts (figures,tables) or in } \\
\text { its entirety can be found online at: } \\
\text { http://www.neurology.org/about/about_the_journal\#permissions }\end{array}$ \\
\hline Reprints & $\begin{array}{l}\text { Information about ordering reprints can be found online: } \\
\text { http://n.neurology.org/subscribers/advertise }\end{array}$ \\
\hline
\end{tabular}

Neurology ${ }^{\circledR}$ is the official journal of the American Academy of Neurology. Published continuously since 1951, it is now a weekly with 48 issues per year. Copyright @ 2015 American Academy of Neurology. All rights reserved. Print ISSN: 0028-3878. Online ISSN: 1526-632X.

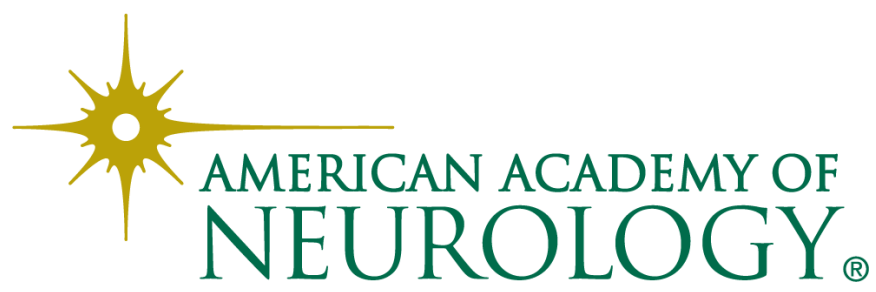

